\title{
sciendo
}

\section{Identification of Information System Audit Quality Factors}

\author{
Amra Alagić \\ Banking Agency of the Federation of Bosnia and Herzegovina \\ amra.alagic@gmail.com \\ Lejla Turulja \\ University of Sarajevo - School of Economics and Business \\ lejla.turulja@efsa.unsa.ba \\ Nijaz Bajgorić \\ University of Sarajevo - School of Economics and Business \\ nijaz.bajgoric@efsa.unsa.ba
}

\begin{abstract}
The primary purpose of this work is to provide an overview and comparative analysis of various Information System Audit Quality measures, as well as to test the validity of the chosen measurement scale empirically. In this regard, a thorough literature study was undertaken, followed by primary empirical research, and the reliability and validity of the measurement scale were tested. Based on the identified papers, a questionnaire was created and evaluated by a panel of experts. Following that, data was collected from respondents who were either managers inside the organizational unit responsible for information technology or those designated as adequate by the heads of IT departments.
\end{abstract}

Keywords: IT audit, audit of information system, audit quality, audit of information system quality, information system audit quality factors

Paper type: Research article

Received: November 20, 2021

Accepted: December 20, 2021

Citation: Alagić, A., Turulja, L., Bajgorić, N. (2021), "Identification of Information System Audit Quality Factors”, Journal of Forensic Accounting Profession, Vol. 1, No. 2, pp. 1-28. DOI: https://doi.org/10.2478/jfap-2021-0006 
The CEO, internal IT auditors, and persons responsible for information system security, as well as those who are in contact with IT auditors during the audit of the information system and have sufficient knowledge of the audit process and processes that are subject to IT audit, were among the respondents in this study.

The convenient sample size was 107 observations, and the proposed measurement scale was analyzed and validated using a confirmatory factor analysis technique. Finally, the findings demonstrate that Information System Audit Quality is a second-order reflective construct with five first-order variables and 19 statements.

The findings of this study contribute to the existing literature by empirically validating a potential measurement scale for information system audit quality. The presented findings contribute to a better understanding of the quality factors of information system auditing in Bosnia and Herzegovina, where information system auditing is an insufficiently regulated domain.

\section{Introduction}

When it comes to information technology management, information technology (IT) audit or IT audit is a modern and advisory function that can be termed the "right hand" of management (Radovanović, Radojević, Lučić \& Šarac, 2010). Organizations must digitally transform their businesses in order to survive in the market and remain competitive, with the phrase "digital or die" best reflecting changes in the business environment (Spremić, 2017). Cyberattacks, on the other hand, which cause disruptions in the normal operation of information systems and the loss of sensitive data as a result of malicious actions are becoming more common (Ben-Asher \& Gonzalez, 2015). As a result, among other things, two major trends in global business can be seen: digital transformation and the improvement of cyber security.

The information system, on the other hand, is the lifeblood of any corporation (Sayana, 2002). In today's world, doing business without an information system is impossible. An organization's IT departments are no longer only business support but strategic partners of management. The most valuable asset is information, which is accompanied by change,

flexibility, speed, and innovative thinking (Kayrak, 2014). At various levels within the organization, the value of information systems and information technology are assessed (Davern \& Kauffman, 2000). Furthermore, when it comes to IS, certain areas are regulated by standards or legislation. It is necessary to perform IT audit on a continuous basis in order to 
ensure that companies operate in line with standards and comply with regulations, laws, and bylaws. IT auditors and IT audit functions are responsible for monitoring, controlling, and auditing all systems, including information systems (Spremić \& Panian, 2012). The issue of audit quality and the factors that influence audit quality has drawn the interest of academics, practitioners, and regulators for many years (Sulaiman, 2011). Previous research has identified a number of attributes that have been suggested to have a positive or negative impact on the quality of IT audits. These attributes include the various characteristics of the process or system being audited, the procedures or techniques used in the audit process, the treatment of audit staff, organizational conditions, and many others.

However, there is no consensus in the literature on how to define information system audit quality. When it comes to measuring the information systems audit quality, three studies stand out, according to a review of the literature (Stoel et al. (2012); Havelka \& Merhout, 2013; and Putri \& Mardijuwono, 2020). Despite the fact that these authors have addressed the issue of information system audit quality, it is clear that no measuring scale has been validated. In this context, the purpose of this article is to identify the factors of information system audit quality and to empirically evaluate the offered measuring scale using primary research.

In this regard, the concept of information systems audit, as well as the IS audit quality, will be provided first in the discussion that follows. Then, it will be presented research process, followed by a section with data analysis. Finally, the main findings of the research are summarized at the conclusion.

\section{Literature review}

\subsection{Audit of information system}

In the past, electronic data processing auditing was commonly used to refer to IT auditing. Due to the rising role of IT in the business environment, the phrases information technology audits and information systems audits have been used in recent years, which has affected the change in language (Kayrak, 2014). IT audit can simply be defined as an audit of an organization's IT systems, operations, and management, as well as other related processes. An information system audit is a systematic procedure for determining whether information technologies and information systems are operating in accordance with business objectives, to what extent they are effectively and efficiently supporting business objectives, and what management and control practices are in place at various hierarchical levels (Spremić, 2017).

In other words, auditing is a process of evaluating the success of information systems in light of what the business expects from them or the opportunities that their application in the 
business provides. IT audits check whether the proper IT control is in place and how successful it is; gather arguments and evidence that can be used to analyze business risks and provide recommendations for their minimization, resulting in better information system and business management. For this reason, it is the process of assessing the quality of information systems through procedures to analyze their impact on business and verify their accuracy, efficiency, effectiveness and reliability. It is a set of complex managerial, auditing, and technological actions that examine (check) the effects, as well as the risks, of using information systems, and ultimately assess their business impact. It is a complex process of gathering evidence on which the effectiveness and maturity of IT controls can be measured, i.e. a systematically and methodologically based evaluation technique:

a) Does IT support business objectives,

b) To what extent does it effectively and efficiently support business objectives, and

c) What is the practice (maturity) of information system management and control at various hierarchical levels?

Companies must constantly reinvent their products and services, as well as use and deploy advanced technologies, in order to remain competitive in the market. Regardless of how dynamic the information technology sector is, the demands placed on IT auditors are continuously evolving. IT audit can help ensure more careful spending of money, as well as provide an adequate system of internal control within the organization's information system, by ensuring adequate IT project management, IT risk assessment and management responsibilities, clear rules for procurement, management, and contracting of IT resources, and adequate change management. The auditing profession has evolved over time since it has unavoidably had to adapt to market changes. This profession must continue to evolve at a faster rate as a result of the introduction of many new technologies such as cloud computing, big data, blockchain, and other IT trends. IT auditors are expected to be creative, forward-thinking, and fearless in the face of change.

IT auditors are hired by companies to determine whether the internal control system is properly designed and safeguards are in place. IT auditors examine and analyze the following three components of the information system during an information system audit:

a) Availability - Are information systems and information available?

b) Security - Is the data and information stored in these systems available only to authorized individuals?

c) Integrity - Is the data and information from the information system accurate, timely and reliable? 
IT auditors conduct an audit of the information system to evaluate the logical, physical, and application controls that have been applied. As a result, IT auditors are responsible for evaluating the company's information system's security and reliability. Furthermore, the information system audit assesses whether the company complies with relevant laws and regulations relating to the management and security of information systems, and the auditors provide their assessment of the company's compliance with applicable laws and regulations in force and relating to the given industry.

IT auditors require specific knowledge, skills, and competences in order to conduct information system audits effectively and efficiently. Auditors can earn a variety of certificates around the world to increase their abilities to conduct information system audits. The most well-known is the CISA certificate (Certified Information System Auditor) issued by the ISACA (Information System Audit and Control Association).

In order to conduct their tasks as efficiently as possible, IT auditors use a variety of standards and norms. CobIT (Control Objective for Information and Related Technology) is a key standard for information system management and auditing. There are also other standards that focus on improving the management of a specific area of the information system or sections of it, or that cover a narrower or more specific area of IT management, such as:

- Management of business information systems development (CMMI, TickIT,...)

- Management of IT services (ITIL)

- $\quad$ IT investment management (Val IT)

- IT risk management (Risk IT, PCI DSS, Basel III, ISO 27005)

- Security management of business information systems (ISO 27000 norms, NIST, SANS, ...)

- Project management (PMBOK, Prince 2)

- Business continuity management (BS 25999).

Due to the fact that information system audit is a process with a beginning and an end, the project approach to information system audit can be used. Individual steps might be completed at the same time, although the audit is usually completed sequentially. In addition, an audit is a cyclical process that assesses risk, analyzes controls, reports to management, and then incorporates audit results into risk assessment using historical and current information (Senft \& Gallegos, 2013).

The audit consists of the following phases (Bajgorić, Turulja, Ibrahimović \& Alagić, 2020):

\section{Audit preparation and planning}


a. Defining the scope of the audit

b. Formulating audit objectives

c. Identifying audit criteria

\section{Conducting an audit}
a. Performing audit procedures
b. Documentation analysis
c. Gathering audit evidence

\section{Preparation of the audit report}

a. Analysis and evaluation of audit evidence

b. Forming audit conclusions and opinions

c. Management (stakeholder) reporting

\section{Post-audit activities}

a. Follow-up

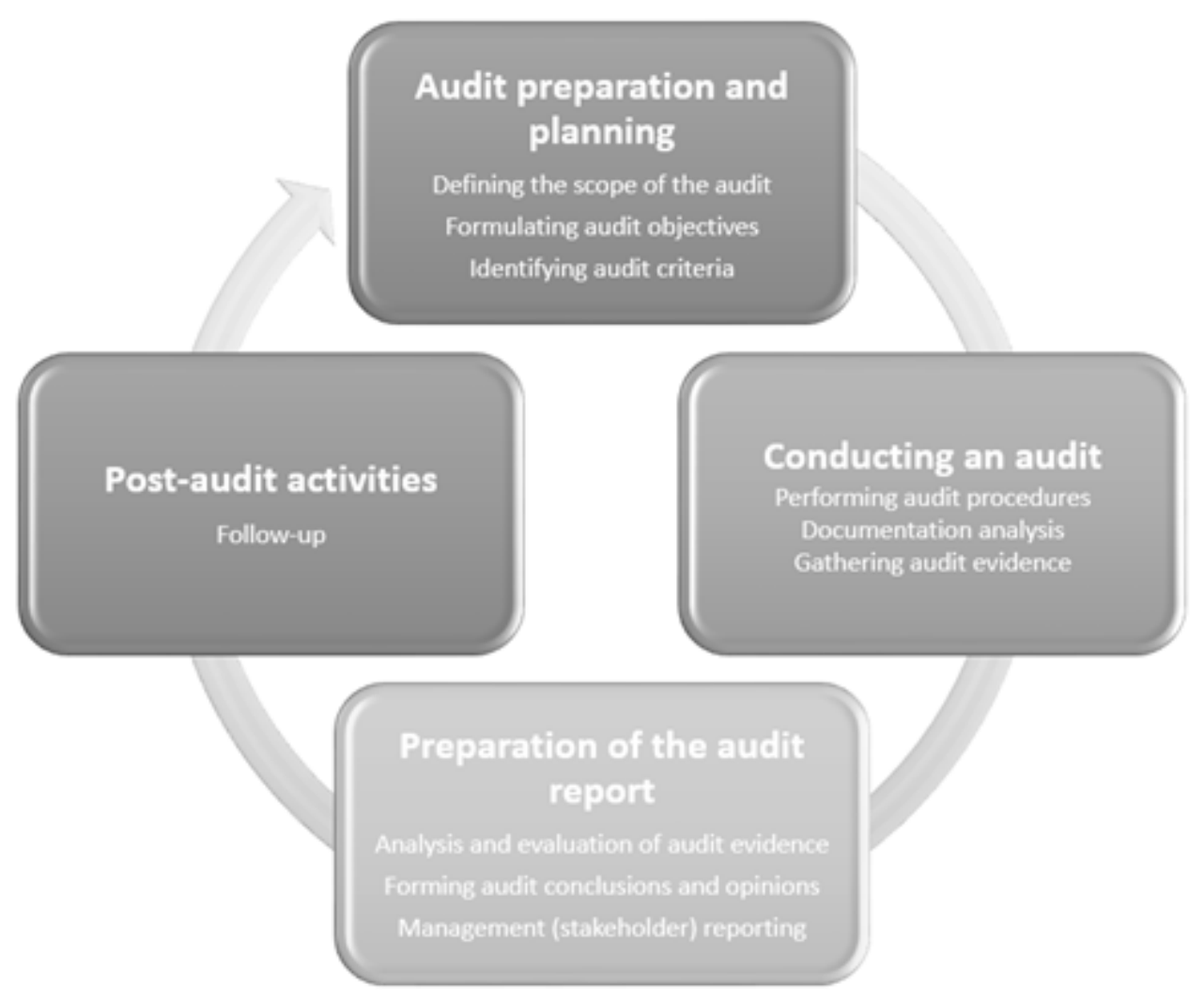

Figure 1. IT Audit Process

The goal of an information system audit is to conduct a systematic and analytical assessment of all controls placed within various segments of the information system, with the primary goal of determining their present status and maturity. As a result, IT auditors should 
identify risk areas, analyze risk levels, and give management recommendations for improving the system of internal controls. Therefore, IT auditors need to implement the following steps:

1. Evaluate the existing status and maturity of the use of information technology in company, based on individual IT areas (segments),

2. Assess the risks they have identified within the information system and

3. Provide management with recommendations for solving a problem, such as enhancing the internal control system.

The basic objectives of conducting an information system audit are as follows:

- Determine the maturity level of each section of the information system,

- Evaluate the impact of information technology on business, i.e., how well the company's information systems enable business process innovation and improve the company's competitiveness,

- Assess, analyze and test the effectiveness of implemented IT controls,

- Identify risk areas and assess the levels of risk to which the company 's operations are exposed and

- Provide recommendations to management on how to introduce more safeguards and controls to reduce or eliminate risks.

\subsection{Audit of information system quality}

Currently, there is almost no consensus on how to define audit quality, and there are different frameworks and conceptualizations that are incomplete (Knechel, Krishnan, Pevzner, Schefchik \& Velury, 2012). There is evidence of a number of major perceptual discrepancies in audit quality between auditors and their clients, according to Hopkins (1997). In essence, the perception of audit quality may depend on the perspective from which it is viewed. According to behavioral studies, there is a lengthy list of criteria that are crucial in determining audit quality, and the relevance of these attributes varies significantly among stakeholders (Knechel et al., 2012). A good audit, according to Knechel et al. (2012), is one in which a very well-designed audit process is carried out by sufficiently motivated and educated auditors who understand the hidden risks of the audit and effectively adjust to the client's unique special conditions.

Because the structure of audit quality is multidimensional but invisible, measuring quality is difficult because many factors influence audit quality (Yeghaneh, Zangiabadi \& 
Firozabadi, 2016). Input, output, and underlying factors are the three main dimensions of audit quality from a conceptual standpoint (Yeghaneh, Zangiabadi \& Firozabadi, 2016). Several different quality factors can be linked to all three aspects. One of the most key variables, for example, is the auditor's personal qualities, such as his or her skills and experience, as well as ethical ideals and ways of thinking. Another important input is the audit process. The audit process refers to the appropriateness of audit procedures, the effectiveness of audit tools, and the technical support approach. Audit outputs, on the other hand, have a substantial impact on audit quality since many stakeholders evaluate audit quality based on the audit report that is produced as a result of the audit.

The degree to which an audit complies with auditing standards is frequently used to describe audit quality (Yeghaneh, Zangiabadi \& Firozabadi, 2016). The quality of audit services, on the other hand, is defined as the market-estimated joint chance that a given auditor will (a) find and (b) report a violation in a client's accounting system (DeAngelo, 1981). The possibility that a particular auditor will find a breach is determined by the auditor's technological capabilities, audit processes employed in a specific audit, sample scope, and other factors. The conditional probability of reporting a detected violation is a measure of the independence of the auditor by a given client. A definition of audit quality based on the auditor's capacity to discover and fix errors and manipulations in reported net income can be found in the literature (Davidson \& Neu, 1993).

The position from which audit quality is evaluated can have a big impact on how it's perceived (Knechel et al., 2012). Audit clients, report users, auditors, regulators, and society as a whole - all actors in the financial reporting process may have very diverse perspectives on what constitutes audit quality, affecting the types of indicators they can use to measure audit quality. The user of the financial statements may believe that the high quality of the audit means the absence of significant misstatements. If all procedures and duties were completed satisfactorily while adhering to the auditor's approach, the auditor might consider the audit to have been successfully and qualitatively completed. If the auditor's report may be utilized as protection in court or when disputing the inspection report, the audit firm may conclude that the audit was well done. If an audit is completed in accordance with professional standards, regulators may consider it to be of high quality. Finally, a corporation may regard a high-quality audit to be one that assists it in avoiding the company's or market's economic troubles. In the end, different views suggest different metrics. 
According to a literature review, research on financial audit quality factors is far more common than research on information system audit quality factors. Authors Samelson, Lowensohn, \& Johnson (2006) also researched the impact of audit quality measures on audit client satisfaction in the public sector. Sutton (1993) created and validated a set of critical factors influencing the audit process, as well as an acceptable set of audit quality assessment measures, with the support of groups of experienced auditors from two worldwide accounting firms. Also, Dunakhir (2016) conducted an audit quality attributes survey in Indonesia, taking into account comments from a group of auditors, audit clients, and external report users.

Depending on who the respondents are in the study, different findings were reached on the factors that have the greatest impact on audit quality. For example, according to Carcello, Hermanson, \& McGrath (1992), the following four factors are most important for audit quality: audit team and client experience, audit expertise in the industry in which the company operates, client response time to auditor requirements, and client compliance audits with general auditing standards. Furthemore, according to Sutton (1993), the auditor's experience has a beneficial impact on important audit quality indicators.

\subsection{Audit of information system quality factors}

A comprehensive literature review was conducted first in order to determine the factors of information system audit quality, and the most significant studies in this area were identified. The conclusions of the identified papers are summarized below.

- In one of their first studies on the information system audit quality, authors Havelka \& Merhout (2007) evaluated the aspects that may affect the IT audit process and developed the first model that could be used to improve the audit process' quality. They identified factors that one or more groups evaluated as significant and then developed their first draft of a quality model using a focus group of internal auditors from a large health care goods and services organization. The following factors are grouped into logical categories and serve as the foundation for the IT audit process' quality model: Client, Target Process or System, IT Audit Personnel, IT Audit Organization and Audit Process/Methodology.

- Subsequently, Merhout \& Havelka (2008) re-conducted the study and argued that information system auditing activities might provide value to the business, despite the fact that information technology auditing was often regarded as a "necessary evil" and 
was completely neglected by the IT department. The authors analyzed the factors developed during the field research, which suggested that IT auditing is a separate project that requires a thorough auditing process and sound project management standards. If properly managed, these success factors can lead to high information system audit reports. These authors presented a complete framework for information system audit quality in this study, demonstrating that combining the quality audit process with strong project management principles leads in a high-quality information system audit that adds value to the organization. The framework consisted of the following eight logical categories based on the fact who or what can control, influence or determine a particular factor: 1) Audit Team Factors, 2) Audit Process \& Methodology Factors, 3) Client-Controlled Organizational Factors, 4) IT AuditControlled Organizational Factors, 5) IT Audit Personnel Technical Competency Factors, 6) IT Audit Personnel Social \& Interpersonal Factors, 7) Enterprise \& Organizational Environment Factors, 8) Target Process Or System Factors.

- Authors Stoel, Havelka \& Merhout (2012) conducted a study to examine the attributes identified in earlier studies that were thought to influence the quality of the information system audit process. As a result, the goal of this study was to rationalize potential constructs and develop prospective instruments for measuring them in relation to the quality of information system audits. IT auditors and financial auditors were among those who responded. The results of factor analysis yielded 13 factors: 1) Independence, 2) Accounting knowledge and audit skills, 3) Business process knowledge and experience, 4) Responsiveness, 5) Field work and audit procedures, 6) Business scale and audit scope, 7) Auditability, 8) Auditor experience with auditee, 9) IT and controls knowledge, 10) Planning and methodology, 11) Resource availability, 12) Auditee relationship, and 13 Business environment.

- Authors Havelka \& Merhout (2013) developed a theoretical framework for the process of internal auditing of information systems by gathering data from various sources utilizing the structured group technique, which included IT auditors, IT managers, and financial auditors from three different organizations. After that, the data was evaluated, and 26 concepts were discovered, which were then organized into the following six categories: 1) Audit Organization, 2) Client Organization, 3) Enterprise Environment, 4) Process and Methodology, 5) Target Process or System, and 6) Audit Personnel. Merhout and Havelka, however, do not provide any empirical evidence to support their 
framework or assess the importance of the attributes or categories they propose, despite the fact that they logically categorize the identified attributes (Yeghaneh, Zangiabadi \& Firozabadi, 2016).

- In addition to the aforementioned authors, Yeghaneh, Zangiabadi \& Firozabadi (2016) conducted a study to analyze the factors that influence the quality of information technology auditing from the auditor's perspective, and included factors of adequate responsibility of the audit team, audit framework and procedures, business criteria and audit scope, audit capabilities, etc.

- Autori Rumengan \& Rahayu (2014) used three independent variables: Auditor Competence, Auditor Independence, and Auditor Work Experience, as well as one dependent variable related to Audit Quality, in their analysis. The goal of this study was to see how competency, independence, and experience of auditors affected audit quality.

- Furthermore, the authors Siew, Yeow, Ling Tan \& Grigoriou (2017) identified key factors influencing IT audit quality and conducted empirical study on Malaysian public listed companies. Preliminary results indicated that all factors significantly affect the quality of IT audit: 1) Auditor IT Knowledge and Competencies, 2) Internal Control Knowledge, 3) Target System Complexity and 4) Resources. The following were used as control variables: 1) Auditor Independence, 2) General Accounting and Audit Knowledge, 3) Audit Team Familiarity with Auditee, 4) Audit Team and Audit Interaction, and 5) Audit Team Planning and Methodology. As a result, it has been concluded that greater focus should be made on audit team member education and training in order to guarantee that they have the essential and necessary IT knowledge and competencies to improve audit quality.

- Oktavianto \& Suryandari (2018) conducted a study to examine the role of understanding information systems as a moderating factor influencing auditor experience and audit complexity on audit quality. The conclusion of this study is that the high complexity of the audit will reduce the quality of the audit, and a good understanding of the information system will improve the quality of the audit.

- Putri \& Mardijuwono (2020) conducted a study to determine the relationship between competencies, work experience, professionalism and independence of auditors, and audit quality. The authors propose the following independent variables in their model: Auditor Competence, Auditor Working Experience, Auditor Professionalism, and 
Auditor Independence. It is interesting to note that the variables that the authors described earlier regard to be part of measuring the quality of information system audits are included in this study.

Based on the above literature review, it is clear that information system audit quality is a complex and multidimensional construct (Yeghaneh, Zangiabadi \& Firozabadi, 2016). The quality of an audit, as well as the measurement of audit quality, is influenced by a number of factors. The International Auditing and Assurance Standards Board, on the other hand, claims that the idea of audit quality has yet to be agreed upon, and given the importance of information system, it is evident that this issue deserves much more attention (Hosseinniakani, Inacio \& Mota, 2014).

As previously stated, the authors Havelka \& Merhout attempted to develop a framework for the information system audit quality on four occasions, originally identifying five aspects, then eight factors, then thirteen factors, and finally six factors. However, none of the measurement scales have been fully validated. When developing these measurement scales, different contexts were taken, which created additional problems.

Because none of the cited authors has validated their information system audit quality measurement scale, and because there is no generally accepted measurement scale for information system audit quality, the factor logic is taken from the following three articles for the purposes of this paper by the authors: Stoel et al. (2012), Havelka \& Merhout (2013) and Putri \& Mardijuwono (2020). Because information system auditing is a poorly regulated field in Bosnia and Herzegovina, five indicators were chosen for the objectives of this article in consultation with a panel of experts comprised of three practitioners and three academics.

\section{Empirical research}

The primary research in this paper was conducted using a quantitative research approach, where the data were collected using the survey method.

The research was conducted through the following steps:

- A literature review was conducted first, and several of the most significant conceptualizations and ways to measure information system audit quality were identified. 
- A panel of experts comprised of three academics and three practitioners was contacted, and a questionnaire was developed based on the identified conceptualizations and methods of assessing information system audit quality. The content validity of the scale was tested at this point. Nomological validity was also evaluated, which means that the correlations between the variables were checked to see if they had a theoretical meaning. When translating certain indicators, the effort was made to ensure that the statement's core meaning was preserved.

- The data collection process was completed in the third step.

- The next step was to conduct an analysis of the collected data and make conclusions on how to assess the quality of the information system audit. The data was analyzed using Confirmative Factor Analysis (CFA).

\subsection{Designing a questionnaire}

When it comes to empirical studies, the concept of information system audit quality has been insufficiently analyzed in the literature. Several studies deal with the conceptualization of constructs from a theoretical perspective but without conducting empirical research. In this regard, three key studies have been identified that contain an information system audit quality measurement scale:

- Authors Stoel, Havelka \& Merhout (2012) conducted a study to examine the attributes identified in earlier studies that were thought to influence the quality of the information system audit process. As a result, the goal of this study was to rationalize potential constructs and develop prospective instruments for measuring them in relation to the quality of information system audits. IT auditors and financial auditors were among those who responded. The results of factor analysis yielded 13 factors: 1) Independence, 2) Accounting knowledge and audit skills, 3) Business process knowledge and experience, 4) Responsiveness, 5) Field work and audit procedures, 6) Business scale and audit scope, 7) Auditability, 8) Auditor experience with auditee, 9) IT and controls knowledge, 10) Planning and methodology, 11) Resource availability, 12) Auditee relationship, and 13 Business environment.

- Havelka \& Merhout (2013) used a structured group technique to collect data from a variety of sources, including IT auditors, IT managers, and financial auditors from 
three different organizations, to develop a theoretical framework for the information system internal audit process. The data were analyzed, and 26 concepts were discovered, which were then organized into the following six categories: 1) Audit Organization, 2) Client Organization, 3) Enterprise Environment, 4) Process and Methodology, 5) Target Process or System, and 6) Audit Personnel.

- According to Putri \& Mardijuwono (2020), the quality of an information system audit was measured by assessing the degree of appropriateness of the test with audit standards, as well as the degree of quality of the audit results report. However, in their model, the authors proposed the following independent variables: Auditor Competence, Auditor Working Experience, Auditor Professionalism, and Auditor Independence. It is interesting to note that the variables that the authors described earlier regard to be part of measuring the information system audit quality are included in this study.

Despite the absence of a validated measurement scale, especially in varied research contexts, a panel of experts comprised of three practitioners and three academics from $\mathrm{BiH}$ was consulted with the goal of specifying an adequate measurement scale. After analyzing the above scales and taking into account Stoel et al.'s (2012) observation that some factors require further investigation, the decision was made to use a five-factor scale: Auditor Independence, Auditor Experience, Auditor Competence, Audit Methodology and Client. 27 indicators were selected from the studies from Stoel et al. (2012), Havelka \& Merhout (2013) and Putri \& Mardijuwono (2020). The statements were chosen based on the research environment, the representation of information system auditing in business practice in Bosnia and Herzegovina (excluding in the financial sector), and the examination of individual claim formulation and translation possibilities. As a result, Information System Audit Quality is a second-order construct that is composed of five (5) first-order constructs: Auditor Independence, Auditor Experience, Auditor Competence, Audit Methodology and Client.

The Likert scale was used to rate all statements in the measurement construct, ranging from „,1 - I completely disagree“ to „, 7 - I completely agree“.

\subsection{Data collection process}

Invitations to participate in the research were sent via email, with a link to the online survey included in the body of the message. The major purpose of the questionnaire was to 
collect information in order to identify the information system audit's quality factors. The study was carried out across the entire region of Bosnia and Herzegovina. A total of 27 questions were included in the survey questionnaire. In addition, the survey questionnaire included nine questions regarding the company's demographic data and 1 question about the engagement of information system auditors.

Respondents were informed that the study was anonymous and that the data will only be presented in aggregate form for scientific purposes. A total of 422 invitation emails were sent, and 145 questionnaires were completed. The response rate is $34.36 \%$. Following a study of the respondents' responses and a review of the data, it was determined that 107 observations would be the subject of this research, accounting for $25.35 \%$ of the total number of questionnaire invites sent out.

\section{Data analysis}

\subsection{Data verification}

The IBM SPSS platform version 22 was used to evaluate and verify the data.

The missing data were checked, outliers were identified, data were tested for assumptions of multivariate techniques (normality, homoscedasticity and linearity), and the following was concluded:

- Following the analysis of missing data, observations with more than $10 \%$ missing answers were removed. Following excluded observations, a total of 107 observations were included in the data analysis within this study;

- After the analysis of the outlier identification, it was noticed that there were no outliers, and all observations were retained;

- After testing the data related to the normality of the data, 103 indicators have a positive kurtosis, which means that it represents a leptokurtic distribution, i.e., that it has a stretched form of data distribution. In addition, 26 indicators have a negative kurtosis, which means that it represents a platykurtic distribution, i.e., indicating that it has a flattened data distribution. In addition, all skewness measures (except 4) for all variables are negative, so it can be concluded that the data distribution has shifted to the right. 
- After testing the data related to homoscedasticity, it was concluded that the relationships between the dependent variables are homoscedastic.

- After testing the data for linearity, it was concluded that all data followed the scatter pattern, which means that the assumption of linearity of the data was met. No significant problems related to the multicollinearity of data were observed.

\subsection{Evaluation of reliability and validity of the measurement scale}

In this study, the Information System Audit Quality is conceptualised as a second-order reflective construct with 5 first-order factors. First-order factors have been suggested in earlier studies as follows: Auditor Independence, Auditor Experience, Auditor Competence, Audit Methodology and Client. These first-order factors are measured by the reflective indicators listed in the table below. The codes used in the paper are:

- Auditor Independence - NE

- Auditor Experience - IR

- Auditor Competence - KO

- Audit Methodology - PME

- Audit Client - KL

In order to check the reliability and validity of the measuring scale, confirmatory factor analysis was performed using SmartPLS 3.3 software.

Measuring scale with dimensions, codes and indicators/statements for measuring the construct of the Information System Audit Quality is presented in the following table:

\begin{tabular}{lll}
\hline Dimension & Code & Indicator/statement \\
\hline NE1 & $\begin{array}{l}\text { The members of the audit team made efforts to maintain their } \\
\text { independence both in communication with the client and in establishing } \\
\text { the facts and writing the findings. } \\
\text { The audit has strict quality control procedures for each individual } \\
\text { auditor, which motivates auditors to adhere to key audit principles such } \\
\text { as integrity, confidentiality, objectivity, etc. } \\
\text { Independence }\end{array}$ \\
The audit team provided rational recommendations for improving the \\
system of internal controls in the information system of our \\
organization.
\end{tabular}


NE4 The audit team made adequate and objective conclusions based on the analysis of facts and evidence gathered in the field.

NE5 The members of the audit team have high ethical standards.

NE6 Members of the audit team did not engage in activities that would jeopardize their independence.

\begin{tabular}{|c|c|c|}
\hline \multirow{3}{*}{$\begin{array}{l}\text { Auditor } \\
\text { Experience }\end{array}$} & IR1 & $\begin{array}{l}\text { The audit team had the appropriate experience necessary to audit our } \\
\text { company. }\end{array}$ \\
\hline & IR2 & $\begin{array}{l}\text { The leader of the audit team had at least } 2 \text { years of experience in the } \\
\text { industry in which our company operates. }\end{array}$ \\
\hline & IR3 & $\begin{array}{l}\text { Key audit staff have been engaged in auditing our company for at least } \\
2 \text { years. }\end{array}$ \\
\hline \multirow{8}{*}{$\begin{array}{l}\text { Auditor } \\
\text { Competence }\end{array}$} & KOI & $\begin{array}{l}\text { The audit team provided useful suggestions for the implementation of } \\
\text { security and control measures within the information system. }\end{array}$ \\
\hline & KO2 & $\begin{array}{l}\text { Members of the audit team possess adequate knowledge about internal } \\
\text { controls and business processes. }\end{array}$ \\
\hline & KO3 & $\begin{array}{l}\text { Members of the audit team have knowledge of information security and } \\
\text { the information system. }\end{array}$ \\
\hline & KO4 & $\begin{array}{l}\text { Members of the audit team are well versed in information technology, } \\
\text { have knowledge of the operation of accounting applications, data } \\
\text { processing applications, etc. }\end{array}$ \\
\hline & KO5 & $\begin{array}{l}\text { Members of the audit team have knowledge of specific business } \\
\text { processes and practices in the industry in which our company operates. }\end{array}$ \\
\hline & KO6 & $\begin{array}{l}\text { Members of the audit team are familiar with the unique business } \\
\text { practices and processes of our company. }\end{array}$ \\
\hline & KO7 & $\begin{array}{l}\text { The members of the audit team possess the necessary expertise and } \\
\text { proficiency to effectively audit our company. }\end{array}$ \\
\hline & KO8 & $\begin{array}{l}\text { The audit team had the capacity to identify weaknesses in the internal } \\
\text { control system and to recommend appropriate measures to reduce the } \\
\text { identified risks. }\end{array}$ \\
\hline \multirow{4}{*}{$\begin{array}{l}\text { Audit } \\
\text { Methodology }\end{array}$} & PM1 & $\begin{array}{l}\text { The audit is adequately planned. The audit was conducted within the } \\
\text { planned period, and the audit team was well prepared to begin the audit. }\end{array}$ \\
\hline & PM2 & $\begin{array}{l}\text { The auditor applied a risk-based planning approach based on risk } \\
\text { assessment, and more attention was paid to IT segments that were } \\
\text { recognized as highly critical for our company. }\end{array}$ \\
\hline & $P M 3$ & $\begin{array}{l}\text { The timing of the audit was adequately planned or adjusted to the } \\
\text { company's IT activities. }\end{array}$ \\
\hline & PM4 & $\begin{array}{l}\text { The audit team used an appropriate methodology to plan and conduct } \\
\text { audit activities. Typical steps of the audit process are carried out: } \\
\text { planning, conducting audit activities in the field, analyzing the factual } \\
\text { situation and making adequate conclusions, and then writing a report. }\end{array}$ \\
\hline
\end{tabular}


PM5 The objectives, plan and scope of the audit are communicated between the auditor and our company.

During the field audit, the audit team identified various preventive,

PM6 detective and corrective controls, as well as protective measures implemented in our company.

PM7 The audit team made conclusions based on adequately conducted field testing.

\begin{tabular}{lcl}
\hline KL1 & $\begin{array}{l}\text { Our company provided adequate support in the data collection process. } \\
\text { The business processes of our company are well defined and supported } \\
\text { by adequate documentation. } \\
\text { The employees of our company adequately understood the process and } \\
\text { purpose of the audit. }\end{array}$ \\
\hline KL3 & KL2 & \\
\hline
\end{tabular}

Table 1. Measuring scale with dimensions, codes and indicators / statements for measuring the construct Information System Audit Quality

Several indicators were removed from the scale in the first step of the analysis due to low factor loadings or high correlation with another indicator. Special care was made not to alter the construct's content during this process (in the table, the excluded statements are marked in italic). It is important to mention that a panel of specialists was also consulted at this point.

Internal consistency reliability assessment is performed using Jöreski (1970) composite reliability (CR) value. Higher values usually indicate a higher level of reliability. For example, reliability values between 0.60 and 0.70 are considered "acceptable in exploratory research", values between 0.70 and 0.90 range from "satisfactory to good".

\begin{tabular}{|l|c|c|}
\hline & rho_A & $\begin{array}{c}\text { Composite } \\
\text { Reliability }\end{array}$ \\
\hline Experience & 0,837 & 0,884 \\
Client & 0,702 & 0,833 \\
Competence & 0,904 & 0,931 \\
Methodology & 0,890 & 0,914 \\
Independence & 0,889 & 0,922 \\
\hline
\end{tabular}

Table 2. Reliability of internal consistency for the measurement scale Information System Audit Quality

The data show that measures robust in terms of internal consistency are indexed by composite reliability. Composite reliability of various measures ranges from 0.701 to 0.931 , which exceeds the recommended threshold value of 0.70 (Nunnally, 1978).

In the second step, the validity of the measurement scale was tested, namely the convergent and discriminant validity. Convergence validation is performed by evaluating 
the value of the factor loading of each variable on the proposed construct. Loadings above 0.7 are recommended because they indicate that the construct explains more than $50 \%$ of the variance of the indicator, thus providing acceptable convergence (Hair, Risher, Sarstedt \& Ringle, 2019). The results of the repeated analysis are provided in Table 3: indicators loadings and $t$-statistics for the measurement scale.

\begin{tabular}{|c|c|c|c|c|c|}
\hline & $\begin{array}{c}\text { Original } \\
\text { Sample (O) }\end{array}$ & $\begin{array}{c}\text { Sample } \\
\text { Mean (M) }\end{array}$ & $\begin{array}{l}\text { Standard } \\
\text { Deviation } \\
\text { (STDEV) }\end{array}$ & $\begin{array}{c}\text { T Statistics } \\
(\mid \text { O/STDEV } \mid)\end{array}$ & P Values \\
\hline NE1 <- Independence & 0,841 & 0,839 & 0,050 & 16,725 & 0,000 \\
\hline NE4 <- Independence & 0,867 & 0,867 & 0,027 & 32,057 & 0,000 \\
\hline NE5 <- Independence & 0,864 & 0,860 & 0,046 & 18,807 & 0,000 \\
\hline NE6 <- Independence & 0,889 & 0,883 & 0,042 & 21,018 & 0,000 \\
\hline IR1 <- Experience & 0,886 & 0,886 & 0,032 & 27,916 & 0,000 \\
\hline IR2 <- Experience & 0,879 & 0,875 & 0,040 & 22,224 & 0,000 \\
\hline IR3 <- Experience & 0,771 & 0,768 & 0,064 & 12,045 & 0,000 \\
\hline KL1 <- Client & 0,808 & 0,811 & 0,032 & 25,192 & 0,000 \\
\hline KL2 <- Client & 0,778 & 0,774 & 0,065 & 12,003 & 0,000 \\
\hline KL3 <- Client & 0,784 & 0,785 & 0,052 & 14,966 & 0,000 \\
\hline KO3 <- Competence & 0,908 & 0,906 & 0,024 & 38,038 & 0,000 \\
\hline KO4 <- Competence & 0,886 & 0,882 & 0,033 & 26,844 & 0,000 \\
\hline KO6 <- Competence & 0,862 & 0,861 & 0,026 & 32,923 & 0,000 \\
\hline KO8 <- Competence & 0,857 & 0,855 & 0,039 & 22,261 & 0,000 \\
\hline PM1 <- Methodology & 0,882 & 0,882 & 0,026 & 33,594 & 0,000 \\
\hline PM4 <- Methodology & 0,844 & 0,838 & 0,048 & 17,747 & 0,000 \\
\hline PM5 <- Methodology & 0,778 & 0,772 & 0,060 & 13,012 & 0,000 \\
\hline PM6 <- Methodology & 0,734 & 0,737 & 0,067 & 10,992 & 0,000 \\
\hline PM7 <- Methodology & 0,876 & 0,876 & 0,030 & 29,659 & 0,000 \\
\hline
\end{tabular}

Table 3. Indicator loadings and t-statistics for the measurement scale Information System Audit Quality

Reliability results are given in Table 4. convergent validity for the measurement scale Information System Audit Quality.

- According to Fornell \& Larcker's (1981) guidelines, the Average Variance Extracted (AVE) for each measure is greater than 0.50 (0.625 to 0.749). Accordingly, latent constructs can be explained with at least $62.50 \%$ variance in indicators (Hair, Black, Babin \& Anderson, 2010).

- Cronbach's alpha for all five constructs is greater than 0.70 (from 0.701 to 0.901 ), and it can be confirmed that the NE, IR, KO, PM and KL constructs possess reliability.

\section{\begin{tabular}{c|c} 
Cronbach's Alpha & $\begin{array}{c}\text { Average Variance } \\
\text { Extracted (AVE) }\end{array}$
\end{tabular}}




\begin{tabular}{|l|l|l|}
\hline Experience & 0,805 & 0,718 \\
Client & 0,701 & 0,625 \\
Competence & 0,901 & 0,772 \\
Methodology & 0,881 & 0,680 \\
Independence & 0,888 & 0,749 \\
\hline
\end{tabular}

Table 4. Convergent validity for the measurement scale Information System Audit Quality

Figure 2 presents the measurement scale of Information System Audit Quality after a confirmatory factor analysis in which the above statements are excluded.

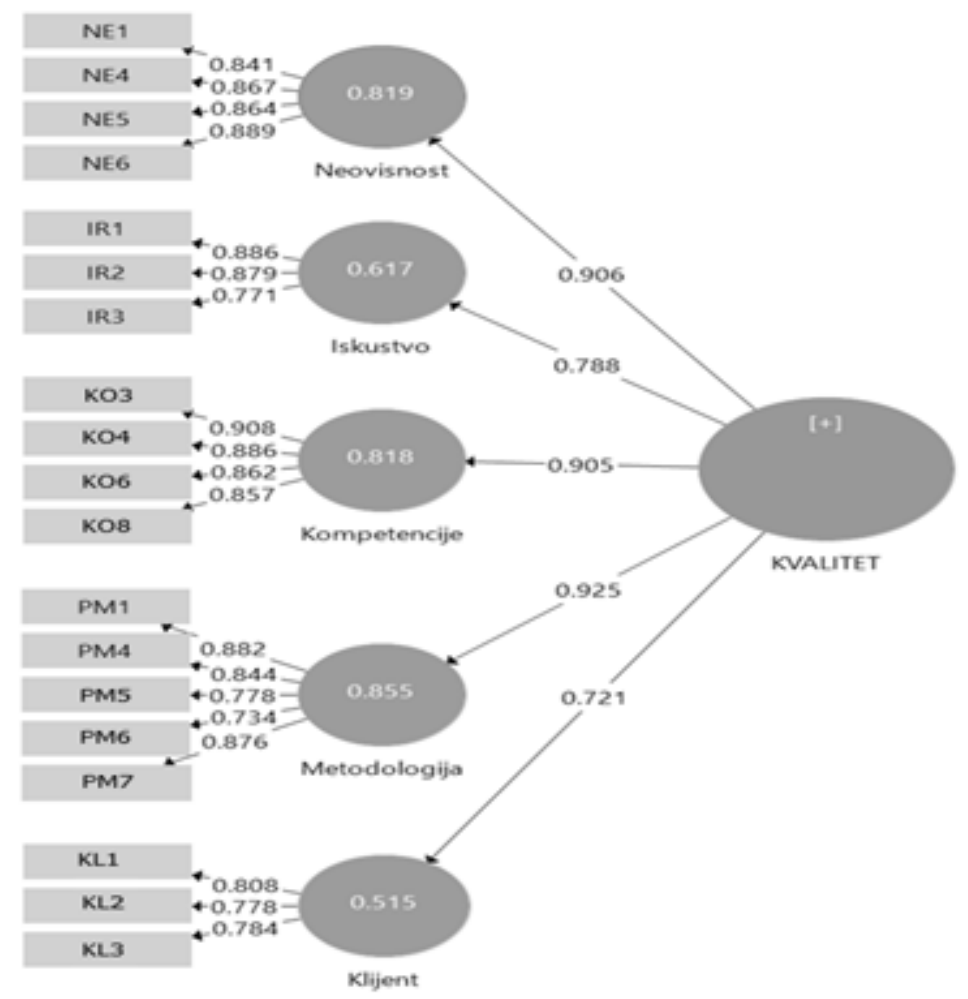

Figure 2. PLS Path Model Estimation - Measurement scale Information System Audit Quality after CFA

In accordance with the indicators analyzed above, it can be determined that the analyzed constructs have the appropriate convergent validity. In other words, the latent constructs NE, IR, KO, PM and KL correlate and share a high proportion of variance.

Discriminant validity is the extent to which a construct differs empirically from other constructs in the structural model. Fornell \& Larcker (1981) proposed traditional metrics and suggested that the square root of the AVE value of each construct should be compared with the correlations of that construct with all other reflectively measured constructs in the model, with the square root of AVE being greater than all correlations. 
Table 5. Discriminant validity - Fornell-Larcker criterion for the measurement scale Information System Audit quality shows the results of examining the discriminant validity of the measures. The elements in the matrix diagonals, which represent the square roots of AVE, are in all cases larger than the elements outside the diagonal in their respective rows and columns, supporting the discriminant validity of this measurement scale.

\begin{tabular}{|l|c|c|c|c|c|}
\hline & Experience & Client & Competence & Methodology & Independence \\
\hline Experience & $\mathbf{0 , 8 4 7}$ & & & & \\
Client & 0,479 & $\mathbf{0 , 7 9 0}$ & & & \\
Competence & 0,644 & 0,586 & $\mathbf{0 , 8 7 9}$ & & \\
Methodology & 0,663 & 0,671 & 0,763 & $\mathbf{0 , 8 2 5}$ & \\
Independence & 0,665 & 0,523 & 0,800 & 0,788 & $\mathbf{0 , 8 6 5}$ \\
\hline
\end{tabular}

Table 5. Discriminant validity - Fornell-Larcker criterion for measurement scale Information System Audit Quality

* The diagonal shows the square root of AVE in bold, and in the lower right triangle the correlations between latent constructs

The Fornell-Larcker criterion is a common and conservative approach for assessing discriminant validity and can also be applied in PLS-based analyzes. However, with this technique, there is another method in which the loading of the indicator on its latent construct should be higher than the loading of other constructs. Table 6. Cross-loadings of reflective constructs clearly show that the discriminant validity presents cross-loadings confirming that loadings on the specified factors are greater than loadings on all other factors.

\begin{tabular}{|l|c|c|c|c|c|}
\hline & Independence & Experience & Competence & Methodology & Client \\
\hline NE1 & $\mathbf{0 , 8 4 1}$ & 0,566 & 0,670 & 0,648 & 0,421 \\
NE4 & $\mathbf{0 , 8 6 7}$ & 0,609 & 0,801 & 0,730 & 0,451 \\
NE5 & $\mathbf{0 , 8 6 4}$ & 0,563 & 0,666 & 0,659 & 0,455 \\
NE6 & $\mathbf{0 , 8 8 9}$ & 0,558 & 0,625 & 0,686 & 0,482 \\
IR1 & 0,669 & 0,671 & 0,672 & 0,497 \\
IR2 & 0,574 & $\mathbf{0 , 8 8 6}$ & 0,529 & 0,553 & 0,371 \\
IR3 & 0,404 & $\mathbf{0 , 8 7 9}$ & 0,391 & 0,422 & 0,324 \\
KO3 & 0,799 & $\mathbf{0 , 7 7 1}$ & 0,585 & 0,721 & 0,538 \\
KO4 & 0,671 & 0,516 & $\mathbf{0 , 8 8 6}$ & 0,623 & 0,499 \\
KO6 & 0,649 & 0,592 & $\mathbf{0 , 8 6 2}$ & 0,603 & 0,509 \\
KO8 & 0,684 & 0,568 & $\mathbf{0 , 8 5 7}$ & 0,728 & 0,511 \\
PM1 & 0,686 & 0,618 & 0,684 & $\mathbf{0 , 8 8 2}$ & 0,562 \\
PM4 & 0,615 & 0,558 & 0,578 & $\mathbf{0 , 8 4 4}$ & 0,605 \\
PM5 & 0,641 & 0,516 & 0,592 & $\mathbf{0 , 7 7 8}$ & 0,624 \\
PM6 & 0,500 & 0,382 & 0,538 & $\mathbf{0 , 7 3 4}$ & 0,457 \\
PM7 & 0,777 & 0,627 & 0,735 & $\mathbf{0 , 8 7 6}$ & 0,519 \\
KL1 & 0,423 & 0,331 & 0,428 & 0,532 & $\mathbf{0 , 8 0 8}$
\end{tabular}




\begin{tabular}{|l|l|l|l|l|l|} 
KL2 & 0,356 & 0,284 & 0,479 & 0,475 & $\mathbf{0 , 7 7 8}$ \\
KL3 & 0,452 & 0,501 & 0,481 & 0,576 & $\mathbf{0 , 7 8 4}$ \\
\hline
\end{tabular}

Table 6. Cross-loadings of reflective constructs for measuring scale Information System Audit Quality

Finally, to check the discriminative validity, it is possible to use the HTMT criterion, which is defined as the mean value of indicator correlations in constructs in relation to the mean value of average correlations for indicators measuring the same construct. Discriminatory validity problems are present when HTMT values are high. Henseler, Ringle \& Sarstedt (2015) propose a limit value of 0.90 for models with constructs that are conceptually very similar.

As it can be seen in Table 7. Heterotrait-Monotrait ratio (HTMT) for the measuring scale Information System Audit Quality, all constructs have a value below 0.90, and it can be determined that the analyzed constructs have the appropriate validity.

\begin{tabular}{|l|c|c|c|c|c|}
\hline & Experience & Client & Competence & Methodology & Independence \\
\hline Experience & & & & & \\
Client & 0,612 & & & \\
Competence & 0,734 & 0,736 & & \\
Methodology & 0,761 & 0,851 & 0,850 & & \\
Independence & 0,765 & 0,658 & 0,889 & 0,883 & \\
\hline
\end{tabular}

Table 7. Heterotrait-Monotrait ratio (HTMT) for measuring scale Information System Audit Quality

Based on the above analysis, it was confirmed that the proposed measurement scale of Information System Audit Quality factors is reliable and valid in the research context of Bosnia and Herzegovina.

\section{Conclusion}

The goal of this paper was to identify the factors of information system audit quality, as well as the method of measuring the information system audit quality, and finally, to empirically test the selected measuring scale. It is crucial to highlight that a review of the existing literature has revealed that the Information System Audit Quality measuring scale has been developed, but there is no consensus on it. Accordingly, for the purposes of this paper, the logic of the factors is taken from three papers: Stoel et al. (2012), Havelka \& Merhout (2013) and Putri \& Mardijuwono (2020).

The research was conducted through the following steps: literature review, data collection and data analysis. 
First, a literature review was undertaken, and several of the most important conceptualizations and methods for assessing the information system audit quality were identified.

A panel of experts comprised of three academics and three practitioners was contacted, and a questionnaire was developed based on the identified conceptualizations and methods of assessing IS audit quality. The content validity of the scale was also tested at this point. The nomological validity of the correlations between the variables was also examined, which means that the correlations have a theoretical meaning. When translating specific indicators, the effort was made to ensure that the statement's core meaning was preserved.

The data collection process was completed in the third step. The major purpose of the questionnaire was to collect information in order to identify the information system audit's quality factors. The study was carried out across the entire region of Bosnia and Herzegovina.

The next step was to conduct an analysis of the acquired data and make conclusions on how to assess the IS audit quality. The data was analyzed using Confirmative Factor Analysis (CFA).

The proposed conceptualization assumes that audit quality is a complex and multidimensional concept. For the purposes of this paper, it was identified that the construct of IS audit quality consists of the following indicators: auditor independence, auditor experience, auditor competence, audit methodology and client and 19 indicators in total.

- Auditor independence is a critical issue for the audit profession. The importance of the client, the providing of non-audit services to avoid conflicts of interest, the auditor's mandate, which can be 5-7 years, and the client's connection with audit companies are all risks to auditor independence (Tepalagul \& Lin, 2015).

- The auditor's experience is critical for conducting the audit, and it is thought that an auditor with more expertise may detect problems and anomalies in the audit client more quickly (Kuntari, Chariri \& Nurdhiana, 2017).

- Auditor competences are the knowledge and abilities required to do the activities that characterize an individual's work, and they can be measured through auditor education, professional certification, continuing education, and other means (Novyarni, 2014). 
- The auditor's work methodology includes determining the audit objectives and scope, planning (including risk assessment), conducting the audit, reporting, and monitoring the recommendations' implementation (Gheorghe, 2010).

- Support and appropriateness of documentation management are two organizational aspects that audit clients control, and it is critical that the audit client cooperates with the auditor (Merhout \& Havelka, 2008).

A comprehensive assessment of conceptualizations and methods of measuring IS audit quality factors, as well as the identification of an appropriate measurement scale by an involved panel of experts, are the contributions of this study. Finally, the measurement scale is also empirically validated. In this way, a better understanding of the process and, in particular, the information system audit quality, is gained. Future studies in the field should test the scale in different research contexts in relation to Bosnia and Herzegovina.

\section{Literature:}

Anderson, J. C., \& Gerbing, D. W. (1988). Structural Equation Modeling in Practice: A Review and Recommended Two-Step Approach. Psychological Bulletin 103(3), pp. 411-423. https://doi.org/10.1037/0033-2909.103.3.411

Bajgorić, N., Turulja, L., Ibrahimović, S., \& Alagić, A. (2020). Enhancing Business Continuity and IT Capability: System Administration and Server Operating Platforms. Boca Raton, FL: CRC Press.

Ben-Asher, N., \& Gonzalez, C. (2015). Effects of cyber security knowledge on attack detection. Computers in Human Behavior 48, pp. 51-61. https://doi.org/10.1016/j.chb.2015.01.039

Carcello, J. V., Hermanson, R. H., \& McGrath, N. T. (1992). Audit quality attributes: The perceptions of audit partners, preparers, and financial statement users. Auditing, 11(1).

Davern, M. J., \& Kauffman, R. J. (2000). Discovering potential and realizing value from information technology investments. Journal of Management Information Systems 16(4), pp. 121-143. https://doi.org/10.1080/07421222.2000.11518268

Davidson, R. A., \& Neu, D. (1993). A Note on the Association between Audit Firm Size and Audit Quality. Contemporary Accounting Research 9(2), pp. 479-488.

DeAngelo, L. E. (1981). Auditor size and audit quality. Journal of Accounting and Economics 3(3), pp. 183-199. https://doi.org/10.1016/0165-4101(81)90002-1

Dunakhir, S. (2016). Factors Associated With Audit Quality: Evidence From an Emerging Market. Second Asia Pacific Conference on Advanced Reserch 2(2), pp. 188-198. 
Fornell, C., \& Larcker, D. F. (1981). Evaluating Structural Equation Models with Unobservable Variables and Measurement Error. Journal of Marketing Research 18(1), pp. 39-50.

Gheorghe, M. (2010). Audit Methodology for IT Governance. Informatica Economica 14(1), pp. 32-42.

Hair, Joseph F., Black, W., Babin, B. J., \& Anderson, R. E. (2010). Multivariate Data Analysis: A Global Perspective. $7^{\text {th }}$ ed. Upper Saddle River, N.J. ; London : Pearson Education.

Hair, J. F., Risher, J. J., Sarstedt, M., \& Ringle, C. M. (2019). When to use and how to report the results of PLS-SEM. European Business Review 31(1), pp. 2-24. https://doi.org/10.1108/EBR-11-2018-0203

Hair Jr, J. F., Hult, G. T. M., Ringle, C., \& Sarstedt, M. (2016). A primer on partial least squares structural equation modeling (PLS-SEM). Los Angeles, CA: SAGE.

Havelka, D., \& Merhout, J. W. (2007). Development of an information technology audit process quality framework. Association for Information Systems - 13th Americas Conference on Information Systems, AMCIS 2007: Reaching New Heights, 2(January 2007), pp. 910-916.

Havelka, D., \& Merhout, J. W. (2013). Internal information technology audit process quality: Theory development using structured group processes. International Journal of Accounting Information Systems 14(3), pp. 165-192. https://doi.org/10.1016/j.accinf.2012.12.001

Henseler, J., Ringle, C. M., \& Sarstedt, M. (2015). A new criterion for assessing discriminant validity in variance-based structural equation modeling. Journal of the Academy of Marketing Science 43(1), pp. 115-135.

Hopkins, R. N. (1997). The Nature of Audit Quality-a Conflict of Paradigms? An Empirical Study of Internal Audit Quality Throughout the United Kingdom Public Sector. International Journal of Auditing 1(2), pp. 117-133. https://doi.org/10.1111/1099-1123.00017

Hosseinniakani, S. M., Inacio, H., \& Mota, R. (2014). A Review on Audit Quality Factors. International Journal of Academic Research in Accounting Finance and Management Sciences 4(2), pp. 243-254. https://doi.org/10.6007/IJARAFMS/v4-i2/861

Jöreskog, K. G. tional T. (1971). Simultaneous factor analysis in several populations. Psychometrika 36(4), pp. 409-426.

Kayrak, M. (2014). Information Technology Audit and the Practice of the Turkish Court of Accounts. Alphanumeric Journal 2(1), pp. 13-22.

Kilgore, A., Harrison, G., \& Radich, R. (2014). Audit quality: what's important to users of audit services. Managerial Auditing Journal 29(9), pp. 776-799.

Knechel, W. R., Krishnan, G. V, Pevzner, M., Schefchik, L., \& Velury, U. (2012). Audit Quality: Insights from the Academic Literature. Auditing: A Journal of Practice \& Theory $32(1)$, pp. 385-421.

Kuntari, Y., Chariri, A., \& Nurdhiana, N. (2017). The effect of auditor ethics, auditor experience, audit fees and auditor motivation on audit quality. Sriwijaya International Journal of Dynamic Economics and Business 1(2), pp. 203-218. 
Lee, L., Petter, S., Fayard, D., \& Robinson, S. (2011). On the use of partial least squares path modeling in accounting research. International Journal of Accounting Information Systems 12(4), pp. 305-328. https://doi.org/10.1016/j.accinf.2011.05.002

Merhout, J., \& Havelka, D. (2008). Information Technology Auditing: A Value-Added IT Governance Partnership between IT Management and Audit. Communications of the Association for Information Systems 23, pp. 463-482.

Novyarni, N. (2014). Influence of internal auditor competence and independence on the quality of financial reporting by municipal/provincial government. International Journal of Economics, Commerce and Management 2(10), pp. 1-14. Retrieved from: http://citeseerx.ist.psu.edu/viewdoc/download?doi=10.1.1.679.7178\&rep=rep1\&type=pdf

Nunnally, J. C. (1978). An overview of psychological measurement. In: Wolman B.B. (eds) Clinical Diagnosis of Mental Disorders. Boston, MA: Springer, pp. 97-146.

Oktavianto, D. D., \& Suryandari, D. (2018). The Factors Affecting the Audit Quality with the Understanding on Information Systems as the Moderating Variable. Accounting Analysis Journal 7(3), pp. 168-175. https://doi.org/10.15294/aaj.v7i3.21008

Putri, R. H. M., \& Mardijuwono, A. W. (2020). The Effect Of Auditor Competence And Independence On Audit Quality. International Journal of Innovation, Creativity and Change 13(9), pp. 1-21.

Radovanović, D., Radojević, T., Lučić, D., \& Šarac, M. (2010). IT audit in accordance with Cobit standard. MIPRO 2010 - 33rd International Convention on Information and Communication Technology, Electronics and Microelectronics, Proceedings, pp. 1137-1141.

Rumengan, I. P. E., \& Rahayu, S. (2014). Pengaruh Kompetensi, Independensi Dan Pengalaman Kerja Terhadap Kualitas Audit (Survei Terhadap Auditor Kap Di Bandung). EProceedings of Management, 1(3).

Samelson, D., Lowensohn, S., \& Johnson, L. E. (2006). The Determinants of Perceived Audit Quality and Auditee Satisfaction in Local Government. Journal of Public Budgeting, Accounting and Financial Management 18(2), pp. 139-166. https://doi.org/10.1179/str.2006.53.4.005

Sayana, S. A. (2002). The IS Audit Process. Information Systems Control Journal 1, pp. 2022.

Senft, S., \& Gallegos, F. (2013). Information Technology Control and Audit. $3^{\text {rd }}$ ed. Boca Raton, FL: CRC Press.

Siew, E.-G., H.P. Yeow, P., Ling Tan, C., \& Grigoriou, N. (2017). Factors affecting IT Audit Quality: an Exploratory Study. Communications of the IBIMA 2017, pp. 1-11. https://doi.org/10.5171/2017.802423

Spremić, M., \& Panian, Ž. (2012). Kontrola i revizija informacijskih sustava. Zagreb: Sveučilište u Zagrebu, Ekonomski fakultet.

Spremić, M. (2017). Digitalna transformacija poslovanja. Zagreb: Sveučilište u Zagrebu, Ekonomski fakultet. 
Stoel, D., Havelka, D., \& Merhout, J. W. (2012). An analysis of attributes that impact information technology audit quality: A study of IT and financial audit practitioners. International Journal of Accounting Information Systems 13(1), pp. 60-79.

Sulaiman, N. A. (2011). Audit Quality in Practice: A Study of Perceptions of Auditors, Audit Committee Members and Quality Inspectors [Doctoral dissertation, University of Manchester]

Sutton, S. G. (1993). Toward an understanding of the factors affecting the quality of the audit process. Decision Sciences 24(1), pp. 88-105.

Sutton, Steve G. (1993). Toward an Understanding of the Factors Affecting the Quality of the Audit Process. Decision Sciences 24(1), pp. 88-105.

Tepalagul, N., \& Lin, L. (2015). Auditor Independence and Audit Quality: A Literature Review. Journal of Accounting, Auditing and Finance 30(1), pp. 101-121. https://doi.org/10.1177/0148558X14544505

Valverde, S. (2016). Major transitions in information technology. Philosophical Transactions of the Royal Society B: Biological Sciences B 371(1701): 2015.0450

Yeghaneh, Y. H., Zangiabadi, M., \& Firozabadi, S. M. D. (2016). Factors affecting information technology audit quality. Journal of Investment and Management 4(5), pp. 196-203. 


\section{Sažetak}

Osnovni cilj ovog rada jeste napraviti pregled i komparativnu analizu dostupnih mjera kvalitete revizije informacionih sistema, te empirijski provjeriti validnost izabrane mjerne skale. S tim u vezi, prvo je proveden detaljan pregled literature, a potom i primarno empirijsko istraživanje, te su provjereni pouzdanost $i$ validnost mjerne skale. Na bazi identificiranih radova je kreiran upitnik koji je evaluiran od strane panela eksperata. Nakon toga je provedeno prikupljanje podataka gdje su ispitanici bili rukovodeća lica u okviru organizacione jedinice odgovorne za informacione tehnologije, odnosno osobe koje ti rukovodioci IT odjela imenuju kao adekvatne. Pored navedenih, ispitanici u okviru ove studije su bili i CEO, interni IT revizori, te lica odgovorna za sigurnost informacionog sistema, kao lica koja su u kontaktu sa IT revizorima za vrijeme provođenja revizije informacionog sistema, te koja imaju dovoljno znanja o procesu revizije i o procesima koji su predmet IT revizije.

Prikladni uzorak se sastojao od 107 opservacija, a za analizu $i$ validiranje predložene mjerne skale je korištena tehnika konfirmativne faktorske analize. U konačnici, rezultati pokazuju da je kvalitet revizije informacionog sistema reflektivni konstrukt drugog reda sa 5 faktora prvog reda, te se sastoji od 19 tvrdnji.

Rezultati ovog istraživanja daju doprinos dosadašnjoj literaturi na način da je empirijski validirana potencijalna mjerna skala kvaliteta revizije informacionog sistema. Ponuđeni rezultati produbljuju razumijevanje faktora kvalitete revizije informacionog sistema u kontekstu Bosne i Hercegovine u kojoj je revizija informacionih sistema nedovoljno zakonski uređena oblast.

Ključne riječi: IT revizija, revizija informacionog sistema, kvalitet revizije, kvalitet revizije informacionog sistema, faktori kvalitete revizije informacionog Sistema 